\title{
Book Review: Interrogating My Chandal Life: An Autobiography of a Dalit by Manoranjan Byapari, translated by Sipra Mukherjee
}

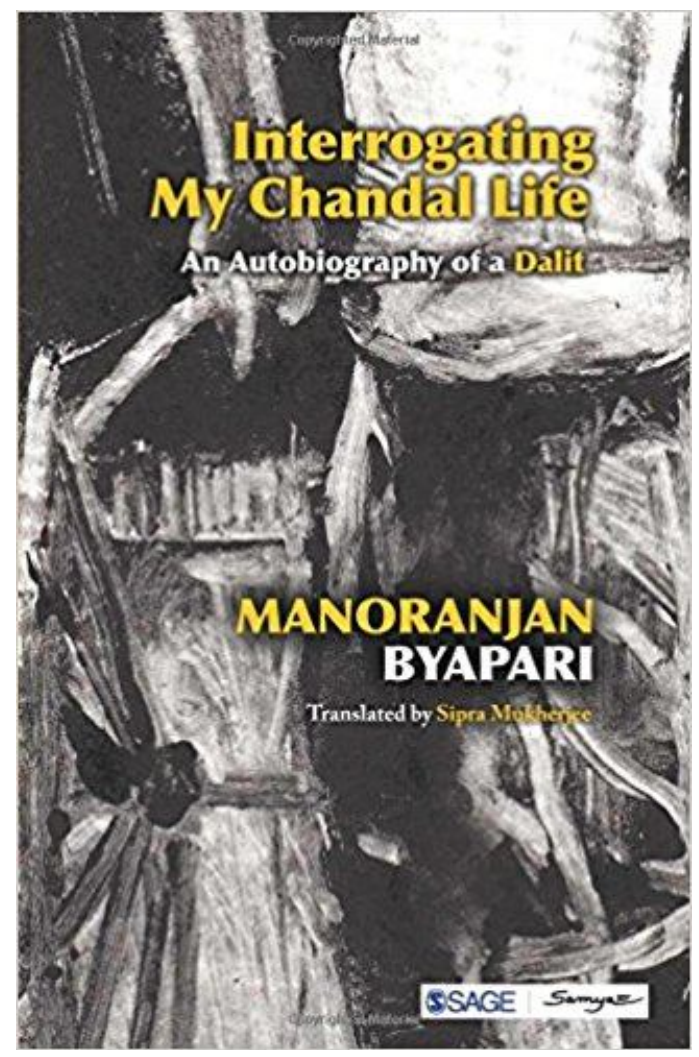

New Delhi/Kolkata: Sage/Samya, 2018, 357 pages, Rs. 318, ISBN: 978-93-813-4530-6(e-Pub)

Reviewed by

Bidisha Pal

Junior Research Fellow, Department of Humanities and Social Sciences, IIT (ISM) Dhanbad, ORCID: oooo-ooo1-9816-3841, Email: bdshpaul6@gmail.com

Dalit autobiographies in India are the oppositional resistant 'micro-narratives' that retrieve "the small voices of history" (Guha, 1996, p. 1-12). The narrative often takes the form of 'witness' or 'testimonial literature'; the narrator simultaneously witnesses and takes part in the events of witnessing. Unlike the Dalits of Maharashtra, Tamilnadu, Karnataka, Gujrat, and Punjab, Dalits in Bengal are the victims of the politics of exclusion in the metanarratives of history and social discourse. Interrogating My Chandal Life: An Autobiography of a Dalit (2018) by Manoranjan Byapari and translated by Sipra Mukherjee is unanimously the first published autobiography of a Bengali Dalit to appear in Bengali as Itibritte Chandal Jivan in 2014. It portrays the journey of a

(c) AesthetixMS 2018. This Open Access article is published under a Creative Commons Attribution Non-Commercial 4.0 International License (http://creativecommons.org/licenses/by-nc/4.0/), which permits non-commercial re-use, distribution, and reproduction in any medium, provided the original work is properly cited. For citation use the DOI. For commercial re-use, please contact editor@rupkatha.com. 
poor, wretched, caste-ridden soul through surrounding socio-political topsy-turvy and tragic upheavals. Belonging to the categorization of lower caste Namashudra or Chandal, Byapari tends to articulate the ultimate excruciating pain of being both a Dalit and poor where caste and poverty become the prime movers in deciding his tragic fate at every step of life."I have lived my life as the ill-fated Dalit son of an ill-fated Dalit father, condemned to a life of bitterness" (Byapari, p.4).

The first two chapters "East Bengal, Partition and West Bengal" and "Dandakaranya Rehabilitation Project, Food Riots and Calcutta" narrate the post-partition trauma and existential crisis of a Dalit refugee who takes birth in the Eight-Brothers' House at Turuk-Khali in Barisal knowingly 'the house of the Byapari's' and belongs to the "Namashuddurs of Kashyap gotra" (Byapari, p.4). Byapari renders the mythic origin and vivid historic descriptions of caste in Bengal with minute allusions to Marich, Namas Muni, Adisura, Pala and Sena dynasty, the British rule of 1872 and the contemptuous Chandal term which the British address the Namashudras with, the rebel of Matua religious leader Guruchand Thakur across Bangladesh, the subsequent emancipation of Namashudra community, the disastrous partition that make a million of hapless people homeless within a couple of months and the evolving communal riots between Hindu and Muslim together what make the Dalit refugee lives worse above everything. To this adds the subsequent creation of colonies and camps on the fringes of Calcutta for the excluded Dalits who initially receive cash dole from the government but that too stops after a few months when rehabilitation project starts. Byapari shows the camp life congestion and trauma where fatal diseases like Cholera, Malaria, and Plague and occasional fisticuffs among the camp dwellers are common and the killings of people are a day to day event. Rehabilitation to the Andaman Islands and Dandakaranya, the politicized projects of the then government make lives twice miserable. Byapari expresses the crisis of situation and personal suffering in Ghola-Doltala and Shiromanipur Camps where "poverty, destitution, starvation and penury" (p.36) are the only truths. He also reveals the hypocrisy of the government leaders who turn a clear niche from the lower caste Namo, Malo, Pod, Bagdi, Jele, Muchi and the Kaoras who are reduced to nothing but sub-human species and the historical Marichjhapi Massacre that results from the superciliousness of the government.

The next four chapters "I Run Away from Home", "My Lone Travels across North and East India", "On the Road for Five Years" and "Return to Calcutta" depict the rootless voyage of a poor boy (his alter ego Jeeban) who runs away from his family and passes through many thick and thin to meet bare sustenance. He undertakes every odd and even sort of job coming on his way in far broader areas of Calcutta, Assam, Siliguri, Darjeeling like working in tea-shops, carrying loads, cooking, washing utensils etc. Byapari exposes the ugly faces of society consisted of both upper caste and class when he gives accounts of the heinous sexual torments twice unleashed on him by the Brahmin head cook Amulya Thakur and the havildar, the cheating of the shopkeeper Sashibabu and thrashing from a ceremony for being of lower caste and his brother Chitta being beaten for the false case of stealing in the hands of the political leaders Anil, Bilu and Basak. Fate etches on every step of his life and he never sticks to one place as he says: "Life has spread skittish mustard seeds under my feet." (Cited in Mukherjee, Preface, 2018)

The initiation to the Naxalite movement starts when he returns back to Calcutta. In chapters "My Entry into the Naxal Movement", "To Dandakaranya and Back to a Changed Calcutta", "Life on and around the Railway Station" and "Bomb Explodes in Barddhaman" Byapari vividly describes his journey within a tumultuous periphery with a rebellious zeal and gesticulation that aim to destroy fundamentalism in society. Byapari introduces us to the fiery 
political personalities like Ashu Majumder, Potato-Swapan, Tata Dutta, and Nanu Das, Khoka Das, Mohit Barman, Khoka Chakraborty that and the everyday political tug of war between the parties, the Naxals and the Police where death in encounters is a frequent business. Byapari himself steps into a death-in-life situation when a bomb explodes in his hand in Barddhaman.

However, Byapari's life starts to transform as seen in the later chapters "Into Jail and the World of Letters", "A Rickshaw-wallhah's Meeting with Mahasweta Devi", "A Girl from the Past", "Marichjhapi", "To Dandakaranya, Dalli and Bastar", "Chhattisgarh, Mukti Morcha and Shankar Guha Neogi" and "After Shankar Guha Neogi". These are the periods when Byapari sheds the cringing identity of lower caste chhotolok into the emancipation into a newer avatar amongst the bhadralok category through entering the world of education inside the jail and brings stability to his fluid life by setting up his own family. Interactions within the wide circumference of stalwarts namely leader Shankar Guha Neogi and his 'Chhattisgarh Mukti Morcha' that makes him reinvigorate the idealism in politics in the region of Dalli, Rajhara, Bastar and Kanker and writer Mahasweta Devi who draws out the writer in him by publishing his writing in the journal Bartika by the name of Madan Dutta, a rickshaw-wallah-writer seem to make his life worth living. With a number of publications (Byapari first makes an attempt to send articles in the pseudo-name Jijibisha to five periodicals Runner, Hatiyar, Vigyan, Sisrikha and Banga Barta; thereafter he continuous to construct literary outputs in forms of a number of novels, short stories and essays and one autobiography) Byapari establishes his identity within the cultural and literary society.

Spivak uses a term "Museumize or protect Subalternity" (Cited in De Kock, p. 46) in order to remind about the tendency to "keep the subaltern in the space of difference by the dubious anthropologistic museumizers" (Cited in De Kock, p. 46) so that their voice cannot be heard. Interrogating My Chandal Life unfolds the very tendency while depicting the heretofore suppressed and alternative history of marginalization of Bengal. It is a staunch Kuntslerroman of an iron-hearted artist. Byapari's struggle for survival from evanescence towards the budding manifestation of being a writer and grabbing a prestigious position in society has several layers underneath. The Preface and the Translator's Note sections serve as the foregrounding of the plot. Each chapter speaks volume for the suffering, trauma and resistance movement in the odyssey of a self-proclaimed hero who launches battalions against the hypocrisy and corrosion of the existing political and social scenario. Strikingly enough, Byapari unveils the garb of nostalgia and musings of past memory with telling truths in different phases of life that can't be more dark and tragic where his childhood spends as "a bare-bodied goatherd running behind his cows and goats with a stick" (Preface, Mukherjee, 2018), boyhood in torn rags with uncombed hair and unclean, dirty appearance devoid of any fantasy kingdom and youth as a rebel Naxalite with bombs and shells and a hideout from the police. In his words, "You've seen me a hundred times in a hundred ways. Yet if you insist that you do not recognize me, let me explain myself in a little greater detail, so you will not feel that way anymore. When the darkness of unfamiliarity lifts, you will feel, why, yes, I do know this person. I've seen this man." (Preface, Mukherjee, 2018).

Byapari plays multiple roles as a Rickshaw-wallah, a Naxalite, a criminal, a cook and a writer in the circle of his Chandal life. Byapari strips off the veil of romantic aestheticism to present the crude reality of Dalit life. His aestheticism lies in the representation of truth that drives the readers towards an alternative artistic value of his autobiography that reminds Sharankumar Limbale's remark: "Dalit writers give priority to problems of society over the entertainment of the readers. They express their feeling in their literature...their effort is not to transport the aesthete-readers to their own level of experience. Because Dalit writers are not focused on the aesthete-reader, traditional aesthetic values, which are aesthete-reader centered, 
are not applicable to the evaluation of their literary productions" (2004, p. 118-119). Byapari has said earlier on the particularity and justification of his writing autobiography in a conversation with Sarangi, "The life that I have lived must be shared with many. I have come back from the jaws of death many times. Recently again I was fighting death, and I had a strong feeling that my life-story must be documented in print, or else it will be lost with me. It's important for people to know that someone survived in such horrid conditions. My writings represent all those people who continue to live in such inhuman circumstances" (J. Sarangi, personal communication, 2012). The stark coarseness and tragic candor of his writing recall that of other Dalit autobiographies like Baluta (1978) by Daya Pawar and Joothan: A Dalit's Life (2003) by Omprakash Valmiki. As Sarbani Banerjee argues in a recent article, "The chhotolok-turned bhadralok characters" in the narratives "form a style of thought detached both from the "elite" and the "underdog" classifications" (Bandyopadhyay, 2017, p. 5). Byapari's autobiography is less a person's experiment and investigation of self and more a socio-political testimony of partitioned and post-partitioned Bengal. Some critics have compared him with Bengal's Maxim Gorky. His recording of events like the 1947 Bengal Partition, the 1959 Food Riots of Calcutta, Dandakaranya Development project of 1958, 1962 Indo-China War, 1971 Bangladesh Liberation War, 1972 Naxalite War, the gruesome 1979 Marichjhapi Massacre constitutes a series of successive montages of a filmic narrative. With jumbling first and third person narrative techniques, the autobiography gives vent for actions than contemplation. The translator Sipra Mukherjee aptly says, "Such action, violent and often desperate, is usually devoid of the cultural baggage that marks our general social movements, occasioning a language that is more universal and less burdened with the specificities of culture." (Translator's Note, Mukherjee, 2018)

According to Mukherjee, "Byapari's prose is urban and modern. Translating the language used by Byapari, therefore, did not pose the many problems that are often faced when translating Dalit literature, where the language embodies its marginalization palpably in the earthiness of its dialect which cannot be kept in translation, which tends to be in standard English" (Translator's Note, Mukherjee, 2018). However, the 'Itibritte' of the original Bengali title has been changed into 'Interrogating' probably for not having an exact English substitution for the Bengali word. Mukherjee further adds a subtitle and this may be for the comprehensibility of the universal readership who can very well relate to a Dalit autobiography and again to whom the very Bengali term Chandal may seem foreign. Following Benjamin's notion of 'Intention' (1996) Mukherjee does not make a word for word translation, translation is done as much as maintaining the thematic essence of the book. Byapari's voluminous life journey has been neatly spanned through the refined threads of plot and storytelling method in the dexterous hand of the translator in chapters that serve as the underpinning of a well-knit historical discourse; although some parts miss detailing and lack information in the translated portion which is also nonetheless a crusade when he encounters into a different struggle of life between the tussling duality of a cook in a deaf and dumb school and a writer desperately trying to establish his identity, instead events of latter part of Byapari's Calcutta and Jadavpur life are winded up in an abridged reflective Epilogue This may be a reason for curtailing the length, not in manner but in volume. Mukherjee retains some Bengali, Chhattisgarhi and Hindi dialects and words like sharanarthis, launda, Ma Durga, payes and panta, babu, Namashudras, Jal-Achal, Chhih chhih, Ka Kha Ga Gha; expressions like Mui lehi nai, Sab jaga tabhi savera, Sab thik ho jayga, Abe la je chal, Puja dekhon, Le chal, Nahi, Kabar, Le, dargho pi! and way of addressing like baba, ma, dada, sala, are, tui that add local color to the translated piece with providing a number of allusive explications at the end of the book to invoke the then associative socio-political and cultural context. "The use of footnotes (or endnotes) is" as Samuel and Samuel note in their article "part of the tendency towards the explication of the 
contents of the translated work. And explication can be useful, useless or harmful, depending on the type of reader one addresses" (2007, p. 378). To some extent, it denotes the untranslatability of the translator but on the other hand, it is apt for constructing a cross-cultural continuum within the local and vernacular and the global and cosmopolitan as the translators of Dalit writings are known to be the 'cultural mediators' or 'cultural activist'. The translation of Dalit writing is a kind of 'Activist Translation' (Mangalam, 2011) and Interrogating may rightly be called so.

Nevertheless, the translated piece fairly happens to be the product of a perfect authortranslator interface and certainly draws commendation for the painstaking effort of the translator. Except for some minute nuances, the book doesn't suffer from any typological or printing errors. Apart from the earlier Surviving in My World: Growing Up Dalit in Bengal (2015) by Monahar Mouli Biswas, Interrogating My Chandal Life is the sole autobiography of a Bengali Dalit in translation that tends to receive a pan-Indian and pan-International readership soon. It provides food for thought and demands serious attention from the readers, critics, academicians, and researchers and all those who share attachments with the Dalit and the Fourth World cause. Moreover, the book paves the way for the opportunities of more translation endeavors to come that would be able to contribute a significant lot in near future to the existing corpora of Dalit literature in English translation.

\section{Reference:}

Bandopadhyay, S. (2017). Different identity formations in Bengali partition narratives by Dalit refugees. Interventions: International Journal of Postcolonial Studies. 19(4). 1-16. DOI: 10.1080/1369801X.2016.1277154.

Benjamin, W. (1996). The task of the translator. In: Marcus. B and Michael. J (Eds.), Selected Writings (Vol. 1), (pp. 253-63). MA: Harvard University Press.

Guha, R. (1996). The small voice of history. In: Amin S and Chakrabarty D (Eds.), Subaltern Studies: Writings on South Asian History and Society (Vol. 9), (pp. 1-12.). New Delhi: Oxford UP.

Kock, De, L. (1992). Interview with Gayatri Chakravorty Spivak: new nation writers conference in South Africa. ARIEL: A Review of International English Literature, 23(3), 29-47. Retrieved from http://jan.ucc.nau.edu/ sj6/SpivakInterviewDeKock.pdf

Limbale, S. (2004). Towards an aesthetic of Dalit literature: history, controversies, and considerations (A. Mukherjee Trans.). Hyderabad: Orient Longman. (Original work published 1996).

Mangalam, B. (2011). Workshop on Dalit writing and translation, Retrieved from http://www.postcolonialtranslation.net/workshop_reports.php.

Samuel, B. M. and Samuel, D.K. (2007). Critical approaches to the notion of translatability and untranslatability of texts in translation studies. Pakistan Journal of Social Sciences, 4(3), 375-379.

Sarangi, J. (Interviewer) \& Byapari, M. (Interviewee). (2012). From Wheels to Stalls: Jaydeep Sarangi in Conversation with Manoranjan Byapari. [Interview Transcript]. Retrieved from Lapis Lazuli -An International Literary Journal / Vol. II/ Issue I /SPRING 2012. Website: http://www.pintersociety.com 